\title{
Activity of Silica in the Slag of an Electric Arc Furnace Using Direct Reduced Iron for Steelmaking
}

\author{
Mohammed MERAIKIB \\ Ministry of Energy and Industry, P.O. Box 2599, Doha, State of Qatar. \\ (Received on December 28, 1994; accepted in final form on March 10, 1995)
}

\begin{abstract}
Test charges consisting of DRI and scrap were melted in a $70 \mathrm{t}$ UHP electric arc furnace. Slag samples were collected and used to estimate the activity coefficient and activity of silica in the slag and to investigate the influences of basicity, temperature and optical basicity on both of them. A relationship between the activity coefficient and temperature was obtained which shows that the relative partial molar enthalpy of solution of $\mathrm{SiO}_{2}$ in the slag is $70.0 \mathrm{~kJ} / \mathrm{mol}$. A simple linear equation has been obtained for the variation of the activity of silica with its concentration in the slag. Metal samples containing from 0.01 to 0.03 wt\% of silicon show that the mean activity coefficient of silicon dissolved in the bath is 0.991 .
\end{abstract}

KEY WORDS: steelmaking with DRI; slag; silica; activity coefficient; activity.

\section{Introduction}

The reaction conditions prevailing in a gas-based direct reduction process do not allow the reduction of the silica in the gangue of the ore used. Therefore, when direct reduced iron (DRI) is utilized for steelmaking, it will be the main source of silica in the slag.

At a certain steelmaking temperature, the activity of silica in the slag depends mainly on the slag basicity. The higher the basicity, the more will be the ability of the slag to react with silica and consequently to lower its activity. The activity of silica in basic steelmaking slags is very low and reaches approximately $10^{-3} \cdot 1$ )

In the present work, the dependence of the activity of silica on slag basicity, temperature and optical basicity is investigated. The changes of the activities with the respective concentrations of silica in the slag and of silicon in the metal bath are also examined.

\section{Experimental}

Metallic charges consisting of DRI having, on average, a degree of metallization of $93.50( \pm 1.0 \mathrm{wt} \%)$ and scrap were melted in a $70 \mathrm{t}$ UHP electric arc furnace of Qatar Steel Company (QASCO). The proportion of DRI in the test charges was varied from approximately 52 to $95 \mathrm{wt} \%$. A detailed description of the experimental procedure has already been published. ${ }^{2)}$ In brief, an initial charge weighing about $35 \mathrm{t}$ of scrap and DRI was charged into the furnace by means of a bucket and power was switched on. Immediately after this charge had started to melt forming a connected molten pool with a temperature of about $1570^{\circ} \mathrm{C}$, DRI and burnt lime were continuously fed into the furnace. As soon as the continuously charged DRI started to melt, the temperature was measured and a pair of samples, one from the slag and the other from the metal, were taken from the furnace for analysis. Temperature measurement and sampling were repeated at different time intervals until metal tapping into the ladle. A slag sample and a metal sample were also taken from the ladle after final deoxidation with ferrosilicon and ferromanganese and temperature measurement.

\section{Results and Discussion}

The data obtained in this investigation will be used to show the effects of slag basicity and temperature on both activity coefficient and activity of silica in the slag and to find a relationship between the activity and the concentration of silicon in the metal bath. The range of the slag composition is given in Table $\mathbf{1}$.

\subsection{Activity Coefficient of Silica in the Slag}

Kozheurov $^{3,4)}$ has obtained the following general formula for the calculation of the activity coefficient, $\gamma_{l}$, of a component $l$ in a slag consisting of $k$ components

$$
\ln \gamma_{l}=\frac{1}{R T}\left(\sum_{i=1}^{l-1} x_{i} Q_{i l}+\sum_{i=l+1}^{k} x_{i} Q_{l i}-\sum_{i=1}^{k-1} \sum_{j=i+1}^{k} x_{i} x_{j} Q_{i j}\right) \text {, }
$$

Table 1. Range of slag composition. (wt \%)

\begin{tabular}{cccccccccc}
\hline $\mathrm{SiO}_{2}$ & $\mathrm{CaO}$ & $\mathrm{MgO}$ & $\mathrm{MnO}$ & $\mathrm{FeO}$ & $\mathrm{Fe}_{2} \mathrm{O}_{3}$ & $\mathrm{Al}_{2} \mathrm{O}_{3}$ & $\mathrm{P}_{2} \mathrm{O}_{5}$ & $\mathrm{~S}$ \\
\hline $13.6-27.1$ & $25.8-52.1$ & $10.2-28.7$ & $0.7-9.6$ & $3.3-12.6$ & $0.80-13.0$ & $3.3-8.3$ & $0.05-0.60$ & $0.004-0.15$ \\
\hline
\end{tabular}


where $x_{i}$ is the cationic fraction of component $i$, which can be calculated from ${ }^{5}$

$$
x_{i}=\frac{v_{i} n_{i}}{\sum v_{i} n_{i}} .
$$

Here, $v_{i}$ is the number of cations in a molecule of component $i$ and $n_{i}$ is the number of moles of the cation in the component per $100 \mathrm{~g}$ of the slag.

The numerical values of the heat of mixing of the components $i$ and $j, Q_{i j}$, used here are ${ }^{3)}$.

$$
\begin{aligned}
& Q_{\mathrm{MnO}_{\mathrm{SiO}}}=-41.8 \mathrm{~kJ}, \\
& Q_{\mathrm{CaO}-\mathrm{SiO}_{2}}=Q_{\mathrm{MgO}-\mathrm{SiO}_{2}}=-113 \mathrm{~kJ}, \\
& Q_{\mathrm{CaO}-\mathrm{P}_{2} \mathrm{O}_{5}}=-200.8 \mathrm{~kJ} .
\end{aligned}
$$

The other values of $Q_{i j}$ are assumed to be equal to zero. Substituting these values of the heat of mixing in Eq. (1), the following formula is obtained for the calculation of $\gamma_{\left(\mathrm{SiO}_{2}\right)}$

$$
\begin{aligned}
& \ln \gamma_{\left(\mathrm{SiO}_{2}\right)}=\frac{5020}{T}\left[\left(x_{\mathrm{FeO}} x_{\mathrm{SiO}_{2}}-x_{\mathrm{MnO}}\right)\right. \\
& +2.71\left(x_{\mathrm{CaO}}+x_{\mathrm{MgO}}\right)\left(x_{\mathrm{SiO}_{2}}-1\right) \\
& \left.+4.82 x_{\mathrm{CaO}{ }} x_{\mathrm{P}_{2} \mathrm{O}_{5}}\right] \text {. }
\end{aligned}
$$

3.1.1. Effect of Slag Basicity on the Activity Coefficient of Silica

Equation (3) was used for the estimation of the activity coefficient of silica in the slag. The results obtained, under the condition of the present investigation, for 100 samples taken in the temperature range $1500 \leq \vartheta \leq 1670^{\circ} \mathrm{C}$ can be given by the following equations

$$
\begin{aligned}
-\ln \gamma_{\left(\mathrm{SiO}_{2}\right)}\left(B_{1}\right)= & 0.434 B_{1}+2.912, \\
& (r=-0.8350, \sigma=0.4330),
\end{aligned}
$$

where $1.19 \leq B_{1} \leq 3.52$ and

$$
\begin{aligned}
& B_{1}=\frac{(\mathrm{CaO})}{\left(\mathrm{SiO}_{2}\right)} \\
& -\ln \gamma_{\left(\mathrm{SiO}_{2}\right)}\left(B_{2}\right)=0.465 B_{2}+2.442 \text {, } \\
& (r=-0.9178, \sigma=0.4508),
\end{aligned}
$$

where $1.94 \leq B_{2} \leq 4.43$ and

$$
\begin{array}{r}
B_{2}=\frac{(\mathrm{CaO})+(\mathrm{MgO})}{\left(\mathrm{SiO}_{2}\right)+\left(\mathrm{P}_{2} \mathrm{O}_{5}\right)} ; \ldots \ldots \ldots \ldots \ldots . . . . . . \\
-\ln \gamma_{\left(\mathrm{SiO}_{2}\right)}\left(B_{3}\right)=0.641 B_{3}+2.293, \\
(r=-0.9391, \sigma=0.3344),
\end{array}
$$

where $1.62 \leq B_{3} \leq 3.47$ and

$$
B_{3}=\frac{(\mathrm{CaO})+(\mathrm{MgO})}{\left(\mathrm{SiO}_{2}\right)+\left(\mathrm{Al}_{2} \mathrm{O}_{3}\right)} \text {. }
$$

These results show that, under the conditions of the present investigation, Eq. (8) gives the best correlation between the activity coefficient of silica and the slag basicity since the absolute value of the correlation coefficient, $|r|$, of this equation is the highest and its standard deviation, $\sigma$, is the lowest. This may be explained by the influence of both $\mathrm{Al}_{2} \mathrm{O}_{3}$ and $\mathrm{MgO}$, which are taken into consideration in $B_{3}$, on the activity co-

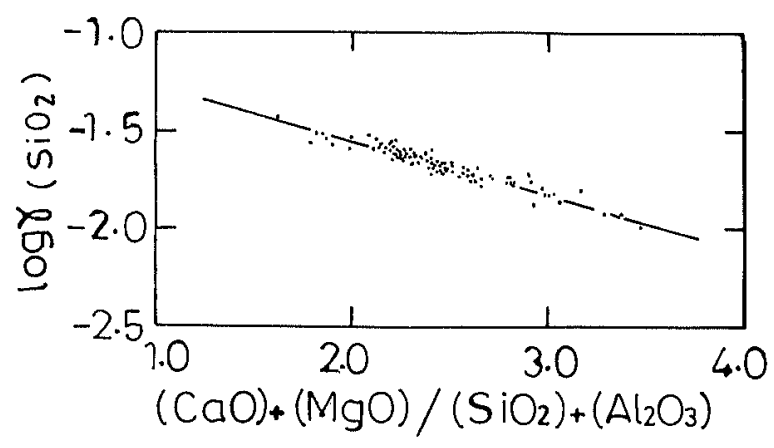

Fig. 1. Relationship between the activity coefficient of silica and the basicity $\{(\mathrm{CaO})+(\mathrm{MgO})\} /\left\{\left(\mathrm{SiO}_{2}\right)+\left(\mathrm{Al}_{2} \mathrm{O}_{3}\right)\right\}$.

efficient of silica.

Figure 1 presents a plot of $\gamma_{\left(\mathrm{SiO}_{2}\right)}$ against $B_{3}$, in semilogarithmic coordinates, with the straight line satisfying Eq. (8). It shows that $\gamma_{\left(\mathrm{SiO}_{2}\right)}$ decreases with increasing basicity as a result of silicate formation due to the reactions of silica with the basic oxides in the slag.

In the present work, however, the concentration of $\mathrm{P}_{2} \mathrm{O}_{5}$ in the slag is low $(0.05-0.60 \mathrm{wt} \%)$, (Table 1$)$. In order to investigate the effect of higher $\mathrm{P}_{2} \mathrm{O}_{5}$ contents on $\gamma_{\left(\mathrm{SiO}_{2}\right)}$, analyses of 30 basic open-hearth slags published in the literature ${ }^{6)}$ were used. The ranges of temperature and $\mathrm{P}_{2} \mathrm{O}_{5}$ content were $1528 \leq \vartheta \leq 1616^{\circ} \mathrm{C}$ and $4.83 \leq$ $\left(\mathrm{P}_{2} \mathrm{O}_{5}\right) \leq 13.48$.

The results obtained can be summarized as follows

$$
\begin{aligned}
-\ln \gamma_{\left(\mathrm{SiO}_{2}\right)}\left(B_{1}\right)= & 0.199 B_{1}+2.760, \\
& (r=-0.6664, \sigma=0.7932),
\end{aligned}
$$

where $2.86 \leq B_{1} \leq 6.50$;

$$
\begin{aligned}
-\ln \gamma_{\left(\mathrm{SiO}_{2}\right)}\left(B_{2}\right)= & 0.382 B_{2}+2.557, \\
& (r=-0.8290, \sigma=0.5134),
\end{aligned}
$$

where $2.00 \leq B_{2} \leq 3.89$;

$$
\begin{aligned}
-\ln \gamma_{\left(\mathrm{SiO}_{2}\right)}\left(B_{3}\right)= & 0.272 B_{3}+2.531, \\
& (r=-0.7208, \sigma=0.6272),
\end{aligned}
$$

where $2.78 \leq B_{3} \leq 5.43$.

Here, the highest absolute value of the correlation coefficient and the lowest standard deviation are obtained when the activity coefficient is correlated with the basicity which includes $\mathrm{P}_{2} \mathrm{O}_{5}$ in its definition, as given by Eq. (11). A comparison of Eqs. (10) and (12) shows that the results achieved by using $B_{3}$ which takes $\mathrm{Al}_{2} \mathrm{O}_{3}$ into consideration are better than those obtained with $B_{1}$ which is only the ratio of $\mathrm{CaO}$ to $\mathrm{SiO}_{2}$ in the slag.

In a trial to find the combined effects of both $\mathrm{P}_{2} \mathrm{O}_{5}$ and $\mathrm{Al}_{2} \mathrm{O}_{3}$ on the activity coefficient of silica in the above mentioned 30 slag samples, the following results were obtained

$$
\begin{aligned}
-\ln \gamma_{\left(\mathrm{SiO}_{2}\right)}\left(B_{4}\right)= & 0.464 B_{4}+2.466, \\
& (r=-0.8530, \sigma=0.4346),
\end{aligned}
$$

where $1.74 \leq B_{4} \leq 3.35$ and

$$
B_{4}=\frac{(\mathrm{CaO})+(\mathrm{MgO})}{\left(\mathrm{SiO}_{2}\right)+\left(\mathrm{P}_{2} \mathrm{O}_{5}\right)+\left(\mathrm{Al}_{2} \mathrm{O}_{3}\right)}
$$




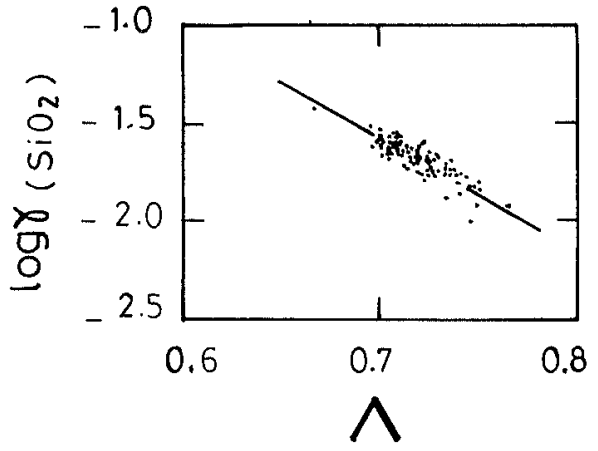

Fig. 2. Relationship between the activity coefficient of silica and the optical basicity.

$$
\begin{aligned}
-\ln \gamma_{\left(\mathrm{SiO}_{2}\right)}\left(B_{5}\right)= & 0.440 B_{5}+2.439, \\
& (r=-0.8511, \sigma=0.4579),
\end{aligned}
$$

where $1.87 \leq B_{5} \leq 3.58$ and

$$
B_{5}=\frac{(\mathrm{CaO})+(\mathrm{MgO})+(\mathrm{MnO})}{\left(\mathrm{SiO}_{2}\right)+\left(\mathrm{P}_{2} \mathrm{O}_{5}\right)+\left(\mathrm{Al}_{2} \mathrm{O}_{3}\right)} .
$$

It is evident that the correlation coefficient and standard deviation of Eq. (13) are better than the corresponding values of Eq. (11), and hence a better correlations is obtained when both $\mathrm{P}_{2} \mathrm{O}_{5}$ and $\mathrm{Al}_{2} \mathrm{O}_{3}$ are taken into consideration when the slag has high $\mathrm{P}_{2} \mathrm{O}_{5}$ contents. The effect of $\mathrm{MnO}$ seems to be very small, probably because of the high concentration of the stronger basic oxides $\mathrm{CaO}$ and $\mathrm{MgO}$ in the slag.

\subsubsection{Effect of Optical Basicity on the Activity Co-} efficient of Silica

The formula used for the calculation of the optical basicity, $A$, is given in the literature. ${ }^{7,8)}$

The results obtained for the 100 samples used in Sec. 3.1.1 are presented in Fig. 2 which shows, in semi logarithmic coordinates, the variation of the activity coefficient of silica with the optical basicity of the slag. The regression equation describing the straight line is

$$
\begin{aligned}
\ln \gamma_{\left(\mathrm{SiO}_{2}\right)}(\Lambda)= & -13.003 \Lambda+5.487, \\
& (r=-0.8673, \sigma=0.0152) .
\end{aligned}
$$

Here, the ranges of optical basicity and temperature are $0.667 \leq \Lambda \leq 0.766$ and $1500 \leq \vartheta \leq 1670^{\circ} \mathrm{C}$.

Figure 2 and Eq. (17) show that the activity coefficient of silica decreases with increasing optical basicity which is the result of silicate formation with the basic oxides in the slag.

\subsubsection{Effect of Temperature on the Activity Coefficient of Silica}

To minimize the influence of a change in the basicity on the activity coefficient of silica, 10 samples having close basicities were selected for the investigation of the effect of temperature on the activity coefficient of silica in the slag. The ranges of basicity and temperature are $2.24 \leq B_{3} \leq 2.58$ and $1565 \leq \vartheta \leq 1655^{\circ} \mathrm{C}$.

Figure 3 shows, in semi-logarithmic coordinates, the variation of $\gamma_{\left(\mathrm{SiO}_{2}\right)}$ with the reciprocal of the absolute temperature for the 10 samples. The regression line satisfies the equation

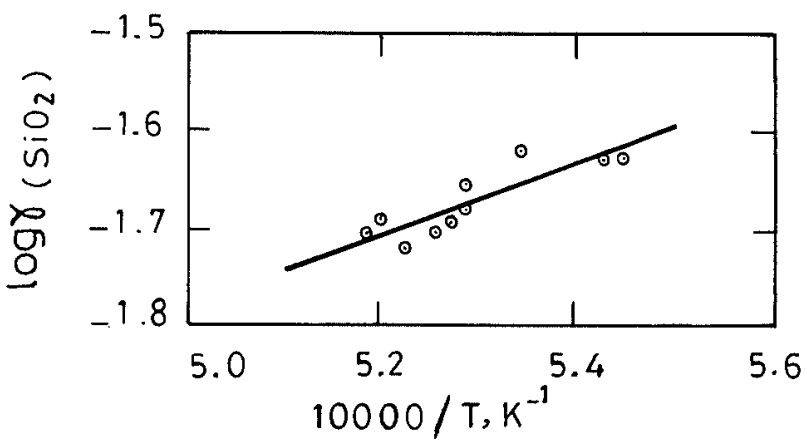

Fig. 3. Relationship between the activity coefficient of silica and the temperature.

$$
\ln \gamma_{\left(\mathrm{SiO}_{2}\right)}(T)=\frac{8423}{T}-8.303, \quad(r=0.8727, \sigma=0.0825) \text {. }
$$

The relative partial molar enthalpy of solution of a component $i, \Delta \bar{H}_{i}$, can be calculated from the following relationship ${ }^{4)}$

$$
\ln \gamma_{i}=\frac{\Delta \bar{H}_{i}}{R T}+\text { constant }
$$

$\Delta \bar{H}_{\left(\mathrm{SiO}_{2}\right)}$ can be estimated by comparison of Eqs. (18) and (19) leading, in the present investigation, to

$$
\Delta \bar{H}_{\left(\mathrm{SiO}_{2}\right)}=70.0 \mathrm{~kJ} / \mathrm{mol} \text {. }
$$

\subsection{Activity of Silica in the Slag}

The activity of silica in the slag, $a_{\left(\mathrm{SiO}_{2}\right)}$, may be given by

$$
a_{\left(\mathrm{SiO}_{2}\right)}=\gamma_{\left(\mathrm{SiO}_{2}\right)} x_{\left(\mathrm{SiO}_{2}\right)} .
$$

The cationic fraction $x_{\left(\mathrm{SiO}_{2}\right)}$ can be calculated by using Eq. (2).

\subsubsection{Effect of Slag Basicity and Temperature on the} Activity of Silica

Similar to the activity coefficient, the activity of silica has been correlated with $B_{1}, B_{2}$ and $B_{3}$ using the above mentioned 100 samples. The following relationships have been obtained

$$
\begin{aligned}
-\ln a_{\left(\mathrm{SiO}_{2}\right)}\left(B_{1}\right)= & 0.634 B_{1}+4.240, \\
& (r=-0.8508, \sigma=0.4330), \\
-\ln a_{\left(\mathrm{SiO}_{2}\right)}\left(B_{2}\right)= & 0.693 B_{2}+3.493, \\
& (r=-0.9674, \sigma=0.4507), \\
-\ln a_{\left(\mathrm{SiO}_{2}\right)}\left(B_{3}\right)= & 0.930 B_{3}+3.334, \\
& (r=-0.9626, \sigma=0.3344) .
\end{aligned}
$$

The values of the correlation coefficient of Eqs. (23) and (24) are almost equal; the standard deviation of Eq. (24), however, is smaller. It seems, therefore, that, as in the case of activity coefficient, the correlation between the activity of silica and $B_{3}$ gives the most satisfactory result.

The regression straight line in Fig. 4 shows the relationship between the activity of silica and the basicity of the slag, $B_{3}$, and satisfies Eq. (24). The decrease of $a_{\left(\mathrm{SiO}_{2}\right)}$ with increasing basicity is the result of silicate formation with the basic oxides of calcium and magnesium. 




Fig. 4. Relationship between the activity of silica and the basicity $\{(\mathrm{CaO})+(\mathrm{MgO})\} /\left\{\left(\mathrm{SiO}_{2}\right)+\left(\mathrm{Al}_{2} \mathrm{O}_{3}\right)\right\}$.

In order to investigate the influence of higher concentrations of $\mathrm{P}_{2} \mathrm{O}_{5}$ in the slag on the variation of the activity of silica with the basicity, the above mentioned 30 basic open-hearth slags were used. The following results were obtained

$$
\begin{aligned}
-\ln a_{\left(\mathrm{Si}_{2}\right)}\left(B_{1}\right)= & 0.408 B_{1}+3.997, \\
& (r=-0.9181, \sigma=0.7932), \\
-\ln a_{\left(\mathrm{Si}_{2}\right)}\left(B_{2}\right)= & 0.647 B_{2}+3.966, \\
& (r=-0.9430, \sigma=0.5134), \\
-\ln a_{\left(\mathrm{Si}_{2}\right)}\left(B_{3}\right)= & 0.530 B_{3}+3.641, \\
& (r=-0.9438, \sigma=0.6272), \\
-\ln a_{\left(\mathrm{Si}_{2}\right)}\left(B_{4}\right)= & 0.748 B_{4}+3.910, \\
& (r=-0.9220, \sigma=0.4346), \\
-\ln a_{\left(\mathrm{Si}_{2}\right)}\left(B_{5}\right)= & 0.703 B_{5}+3.879, \\
& (r=-0.9138, \sigma=0.4580) .
\end{aligned}
$$

The values of the correlation coefficient of Eqs. (25) to (29) indicate a good correlation of the activity of silica with the slag basicities. Equation (28), however, shows that the least standard deviation is obtained with $B_{4}$ which takes both $\mathrm{Al}_{2} \mathrm{O}_{3}$ and $\mathrm{P}_{2} \mathrm{O}_{5}$ into account.

Besides the effect of the basicity, the activity of silica is also influenced by the temperature. In order to investigate the combined effects of both basicity and temperature on the activity of silica in the slag, $a_{\left(\mathrm{SiO}_{2}\right)}$ has been plotted, in semi-logarithmic coordinates, against $B_{3}$ at constant temperature as shown in Fig. 5. The straight lines are almost parallel and may be described by the equation

$$
\ln a_{\left(\mathrm{SiO}_{2}\right)}\left(B_{3}, T\right)=-0.920 B_{3}+b,
$$

where -0.920 is the average value of the slopes of the three lines, and

$$
\begin{array}{rr}
b & =-3.296 \text { at } 1550^{\circ} \mathrm{C}, \quad(r=-0.9978, \sigma=0.4627), \\
& =-3.352 \text { at } 1570^{\circ} \mathrm{C}, \quad(r=-0.9676, \sigma \ldots \ldots \ldots \ldots \ldots . .(31) \\
\ldots \ldots \ldots \ldots \ldots \ldots \ldots \ldots . .(32) & \\
& =-3.456 \text { at } 1630^{\circ} \mathrm{C}, \quad(r=-0.9885, \sigma=0.2316) .
\end{array}
$$


Fig. 5. Relationship between the activity of silica and the basicity $\{(\mathrm{CaO})+(\mathrm{MgO})\} /\left\{\left(\mathrm{SiO}_{2}\right)+\left(\mathrm{Al}_{2} \mathrm{O}_{3}\right)\right\}$ at constant temperature.

These values of $b$ can be related to the temperature by

$$
b=\frac{6728}{T}-6.994 \text {. }
$$

Substituting $b$ in Eq. (30) from Eq. (34), it follows that

$$
\ln a_{\left(\mathrm{SiO}_{2}\right)}\left(B_{3}, T\right)=\frac{6728}{T}-\left(0.920 B_{3}+6.994\right) .
$$

This equation shows that the activity of silica in the slag decreases with increasing temperature and basicity. The decrease of $a_{\left(\mathrm{SiO}_{2}\right)}$ with increasing slag basicity and temperature can also be inferred from the measurements of other investigators. ${ }^{9)}$

3.2.2. Effect of Optical Basicity on the Activity of Silica

The variation of the activity of silica in the slag with the optical basicity, $A$, is illustrated in Fig. 6. The regression straight line obtained for the 100 samples, already used to show the influence of the basicity on the activity of silica, can be described by the formula

$$
\begin{aligned}
\ln a_{\left(\mathrm{SiO}_{2}\right)}(\Lambda)= & -18.189 \Lambda+7.467, \\
& (r=-0.8572, \sigma=0.0152) .
\end{aligned}
$$

Similar to Eqs. (22) to (24), Eq. (36) shows that the logarithm of the activity of silica in the slag decreases linearly with increasing optical basicity due to silicate formation.

\subsubsection{Effect of the Concentration of Silica on Its Activity}

In an attempt to find if a simple formula could be obtained which relates the activity of silica to its 




Fig. 6. Relationship between the activity of silica and the optical basicity.

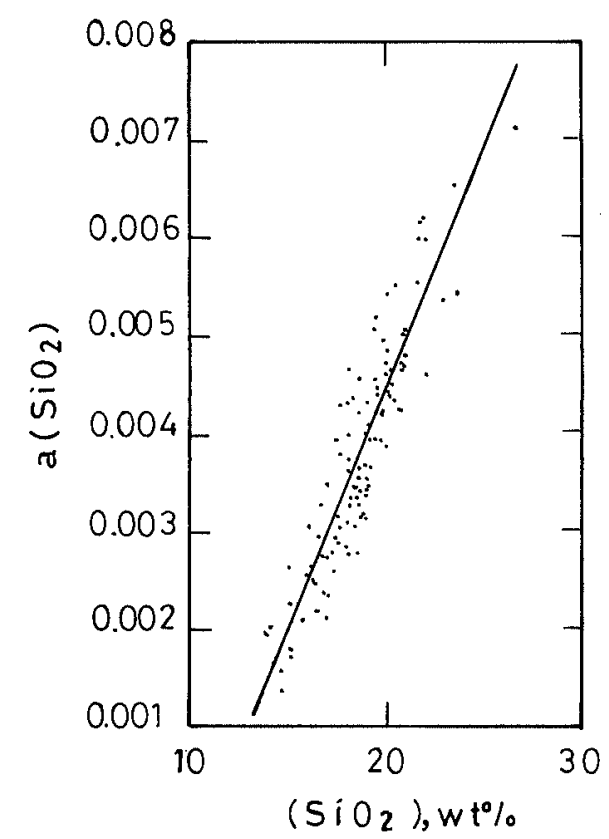

Fig. 7. Relationship between the activity and the concentration of silica.

concentration in the slag, a correlation of 109 values of activity with the corresponding concentration of silica in the slag was done. The results are presented in Fig. 7 which shows the following linear relationship

$$
\begin{aligned}
a_{\left(\mathrm{SiO}_{2}\right)}= & 0.00049\left(\mathrm{SiO}_{2}\right)-0.00536, \\
& (r=-0.9064, \sigma=2.1355) .
\end{aligned}
$$

The ranges of silica-concentration (wt $\%$ ), basicity and temperature in which this equation has been obtained are $13.56 \leq\left(\mathrm{SiO}_{2}\right) \leq 26.42,1.58 \leq B_{3} \leq 3.47,1480 \leq \vartheta \leq$ $1670^{\circ} \mathrm{C}$.

\subsection{Activity of Silicon in the Bath}

At low concentration of silicon in the metal bath, the activity of silicon, $a_{[\mathrm{Si}]}$, is related to the concentration, [Si], in percent by weight, by

$$
a_{[\mathrm{Si}]}=f_{[\mathrm{Si}]}[\mathrm{Si}] \text {, }
$$

where
Table 2. Values of interaction parameters $e_{x}^{(i)} \cdot{ }^{10}$

\begin{tabular}{cccccc}
\hline$e_{\mathrm{Si}}^{(\mathrm{Si})}$ & $e_{\mathrm{Si}}^{(\mathrm{O})}$ & $e_{\mathrm{Si}}^{(\mathrm{C})}$ & $e_{\mathrm{Si}}^{(\mathrm{Mn})}$ & $e_{\mathrm{Si}}^{(\mathrm{S})}$ & $e_{\mathrm{Si}}^{(\mathrm{P})}$ \\
\hline$\frac{34.5}{T}+0.089$ & -0.23 & $\frac{38}{T}-0.023$ & 0.002 & 0.056 & 0.11 \\
\hline
\end{tabular}

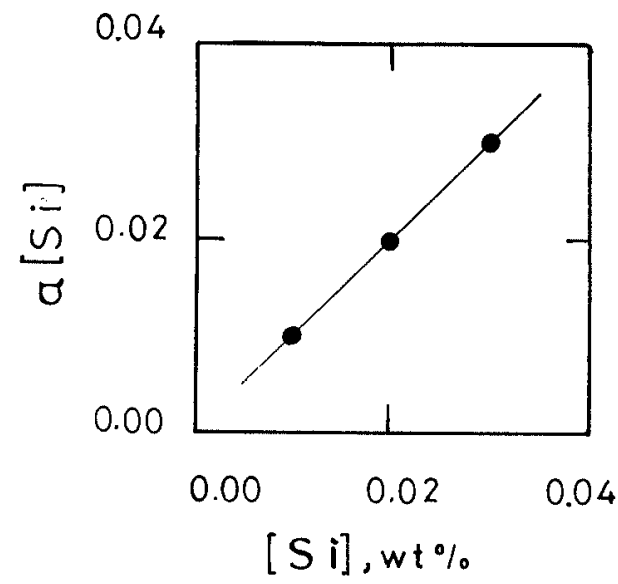

Fig. 8. Relationship between the activity and the concentration of silicon in the metal bath.

$$
\begin{aligned}
\log f_{[\mathrm{Si}]}= & e_{\mathrm{Si}}^{(\mathrm{Si})}[\mathrm{Si}]+e_{\mathrm{Si}}^{(\mathrm{O})}[\mathrm{O}]+e_{\mathrm{Si}}^{(\mathrm{C})}[\mathrm{C}]+e_{\mathrm{Si}}^{(\mathrm{Mn})}[\mathrm{Mn}] \\
& +e_{\mathrm{Si}}^{(\mathrm{S})}[\mathrm{S}]+e_{\mathrm{Si}}^{(\mathrm{P})}[\mathrm{P}]
\end{aligned}
$$

The values of the interaction parameters, $e_{x}^{(i)},{ }^{10)}$ are given in Table 2. They have been used together with the metal analysis to calculate the activity coefficient of silicon according to Eq. (39) and hence the activity of silicon using Eq. (38). The results obtained for 50 samples are plotted in Fig. 8 which represents the variation of the activity of silicon with the silicon concentration in the bath. The regression line satisfies the formula

$$
a_{[\mathrm{Si}]}=0.991[\mathrm{Si}], \quad(r=0.99996, \sigma=0.0059),
$$

which shows a slight negative deviation of the activity of silicon in molten metal from ideal behaviour.

A comparison of Eqs. (38) and (40) leads to

$$
f_{\text {[Si] }}=0.991 \text {. }
$$

The ranges of silicon concentration (wt\%) and temperature in which Eq. (40) has been obtained are $0.01 \leq$ $[\mathrm{Si}] \leq 0.03$ and $1522 \leq \vartheta \leq 1660^{\circ} \mathrm{C}$.

\section{Conclusions}

The charges composed of various proportions of DRI and scrap were melted in a $70 \mathrm{t}$ UHP electric arc furnace. Slag and metal samples were collected at different time intervals. The slag analysis was used to find the effects of slag composition and temperature on the activity coefficient and activity of silica in the slag. The metal analysis was utilized to find a relation between the activity and concentration of silicon in the metal bath. The results were as follows:

(1) The activity coefficient of silica depends on both slag basicity and temperature.

(2) The relative partial molar enthalpy of solution of $\mathrm{SiO}_{2}$ in the slag is $70 \mathrm{~kJ} / \mathrm{mol}$. 
(3) The activity of silica is affected by the basicity and temperature of the slag.

(4) Regression equations are presented which show the influence of the basicity and optical basicity on both activity coefficient and activity of silica.

(5) A linear relationship between the activity and concentration of silica is obtained for silica concentration from 13.56 to $26.42 \mathrm{wt} \%$.

(6) The mean activity coefficient of silicon in the metal bath is 0.991 for silicon concentration from 0.01 to $0.03 \mathrm{wt} \%$.

\section{Acknowledgement}

The author wishes to thank Qatar Steel Company for conducting the tests.

\section{Nomenclature}

$a_{\left(\mathrm{SiO}_{2}\right)}:$ activity of silica in the slag

$a_{[\mathrm{Si}]}:$ activity of silicon in molten metal

$B$ : basicity of slag, $B_{1}=(\mathrm{CaO}) /\left(\mathrm{SiO}_{2}\right)$, $B_{2}=(\mathrm{CaO})+(\mathrm{MgO}) /\left(\mathrm{SiO}_{2}\right)+\left(\mathrm{P}_{2} \mathrm{O}_{5}\right)$, $B_{3}=(\mathrm{CaO})+(\mathrm{MgO}) /\left(\mathrm{SiO}_{2}\right)+\left(\mathrm{Al}_{2} \mathrm{O}_{3}\right)$, $B_{4}=(\mathrm{CaO})+(\mathrm{MgO}) /\left(\mathrm{SiO}_{2}\right)+\left(\mathrm{P}_{2} \mathrm{O}_{5}\right)$ $+\left(\mathrm{Al}_{2} \mathrm{O}_{3}\right)$

$B_{5}=(\mathrm{CaO})+(\mathrm{MgO})+(\mathrm{MnO}) /\left(\mathrm{SiO}_{2}\right)$ $+\left(\mathrm{P}_{2} \mathrm{O}_{5}\right)+\left(\mathrm{Al}_{2} \mathrm{O}_{3}\right)$

$b$ : intercept of the straight line according to Fig. 5 and Eqs. (30) to (34)

$e_{x}^{(i)}$ : interaction parameter

$f_{\text {[Si] }}$ : activity coefficient of silicon in molten metal

$n_{i}$ : number of moles of cation $i$ in $100 \mathrm{~g}$ of slag

$Q_{i j}$ : energy of mixing of components $i, j$

$R:$ gas constant $(\mathrm{J} /(\mathrm{K} \mathrm{mol}))$

$r$ : correlation coefficient
$T:$ absolute temperature (K)

$(x),[x]$ : concentration of species $x$ in slag and metal respectively (wt \%)

$x_{i}, x_{j}$ : cationic fractions of components $i, j$

$x_{\left(\mathrm{SiO}_{2}\right)}$ : cationic fraction of $\mathrm{SiO}_{2}$ in slag

$\gamma_{l}$ : activity coefficient of component $l$ in slag

$\gamma_{\left(\mathrm{SiO}_{2}\right)}:$ activity coefficient of $\mathrm{SiO}_{2}$ in slag

$\Delta \bar{H}_{i}:$ relative partial molar enthalpy of solution of component $i(\mathrm{~J} / \mathrm{mol})$

$\Delta \bar{H}_{\left(\mathrm{SiO}_{2}\right)}$ : relative partial molar enthalpy of solution of $\mathrm{SiO}_{2}$ in slag $(\mathrm{kJ} / \mathrm{mol})$ according to Eq. (20)

\&: temperature $\left({ }^{\circ} \mathrm{C}\right)$

$\Lambda$ : optical basicity

$v_{i}$ : number of cations in a molecule of component $i$

$\sigma: \quad$ standard deviation

\section{REFERENCES}

1) T. Rosenqvist: Principles of Extractive Metallurgy, McGraw-Hill Book Co., New York, (1974), 385.

2) M. Meraikib: Steel Res., 57 (1986), 626.

3) V. Grigoryan, L. Belyanchikov and A. Stomakhin: Theoretical Principles of Electric Steelmaking, Mir Publishers, Moscow, (1983), 73.

4) M. Meraikib: ISIJ Int., 33 (1993), 352.

5) S. Filippov: The Theory of Metallurgical Processes, Mir Publishers, Moscow, (1975), 228.

6) C. Bodsworth: Physical Chemistry of Iron and Steel Manufacture, Longmans, London, First Ed., (1963), 476.

7) D. R. Gaskell: Trans. Iron Steel Inst. Jpn., 22 (1982), 997.

8) M. Meraikib: Steel Res., 59 (1988), 449.

9) N. K. Batra and P. S. Bhaduri: Ironmaking Steelmaking, 17 (1990), 389.

10) V. Grigoryan, L. Belyanchikov and A. Stomakhin: Theoretical Principles of Electric Steelmaking, Mir Publishers, Moscow, (1983), 54. 